\title{
Analisis Kesiapan Pengguna Lective Menggunakan Metode Technology Readiness Index (TRI)
}

\author{
Fath Muhammad Dzulkifli; ${ }^{\star 1}$, Evi Dwi Wahyuni ${ }^{2}$, Galih Wasis Wicaksono ${ }^{3}$ \\ 1,2,3Teknik Informatika/Universitas Muhammadiyah Malang \\ fathmdzulkifli@gmail.com*
}

\begin{abstract}
Abstrak
Lective merupakan sarana pembelajaran online berbasis website yang dirancang bagi dosen untuk mempermudah dalam mendesain Rencana Pembelajaran Semester (RPS) dan Rencana Pelaksanaan Pembelajaran (RPP). dan sistem ini sangat membantu bagi dosen-dosen yang tidak memiliki latar belakang pendidikan maka tools ini sangat membantu bagi mereka. Lective ini masih bisa dikatakan baru dan masih dalam proses pengembangan. kurangnya penerapan Lective di lingkungan Universitas Muhammadiyah Malang merupakan salah satu faktor kendala dalam pengembangannya dikarenakan kesiapan dari penggunanya yaitu dosen yang masih kurang memahami secara penuh tentang penggunaan Lective. Technology Readiness Index (TRI) merupakan indeks untuk mengukur kesiapan pengguna terhadap teknologi baru. TRI menggunakan serangkaian pernyataan kepercayaan/keyakinan dalam melakukan survei untuk mengukur secara menyeluruh tingkat kesiapan teknologi dari individu yang meliputi Optismism, Innovativeness, Discomfort dan Insecurity, Penelitian diawali dengan penyusunan instrumen penelitian, penyebaran kuisioner, dan analisis hasil kuisioner. Berdasarkan hasil analisis, penelitian ini menghasilkan sebuah pernyataan dimana Optimism, Innovativeness, Discomfort dan Insecurity tidak mempengaruhi kesiapan pengguna Lective. Dikarenakan hasil yang didapat berpengaruh negatif terhadap kesiapan pengguna sistem Lective.
\end{abstract}

Kata Kunci: Lective, Kesiapan Pengguna, Technology Readiness Index

\begin{abstract}
Lective is a website-based online learning tool designed for lecturers to simplify the design of Semester Learning Plans (RPS) and Learning Implementation Plans (RPP). And this system is very helpful for lecturers who do not have an educational background so these tools are very helpful for they. This Lective can still be said to be new and still under development. the lack of implementation of Lective in University of Muhammadiyah Malang is one of the obstacles in its development due to the readiness of its users, namely lecturers who still lack full understanding of the use of Lective. Technology Readiness Index (TRI) is an index to measure users' readiness for new technology. TRI uses a series of statements of beliefs / beliefs in conducting surveys to thoroughly measure the level of technological readiness of individuals which includes Optismism, Innovativeness, Discomfort and Insecurity, Research begins with the preparation of research instruments, questionnaire dissemination, and analysis of questionnaire results. Based on the results of the analysis, this study produced a statement where Optimism, Innovativeness, Discomfort and Insecurity did not affect Lective users' readiness. Because the results obtained negatively affect the readiness of the Lective.
\end{abstract}

Keywords: Lective, User Readiness, Technology Readiness Index (TRI)

\section{Pendahuluan}

Perkembangan teknologi di Indonesia kian pesat, salah satunya dalam bidang pendidikan. Berdasarkan entitas dan propertis dari teknologi, sistem informasi akademik merujuk pada seperangkat sistem dan aktivitas yang digunakan untuk menata, memproses dan menggunakan informasi sebagai sumber dalam suatu organisasi yang berjalan (Sprange \& Carlson, 1982). Pemanfaatan Teknologi Informasi dan Komunikasi (TIK) pada bidang akademik di perguruan tinggi menjadi suatu kebutuhan, bukan hanya sekedar prestise terhadap manajemen pendidikan tinggi modern [1]. 
Lective merupakan sebuah perangkat pembelajaran berbasis online, sebagai sarana pembelajaran bagi dosen untuk mendesain Rencana Pembelajaran Semester (RPS) dan Rencana Pelaksanaan Pembelajaran (RPP) untuk mengakomodir kebutuhan seperti yang disyaratkan dalam Permendikbud No. 49/2014 [2]. Dalam pengelolaan Lective ini tentu saja memerlukan kemampuan pedagogik dari dosen, hanya saja bagi dosen yang tidak memiliki latar belakang ilmu kependidikan diperlukan tools untuk merancang RPS dan RPP. Sistem Lective juga menyediakan berbagai template sebagai contoh sekaligus panduan bagi Dosen. Berbagai template teknik, jenis dan instrument penilaian yang disediakan Lective dapat digunakan Dosen dalam kegiatan belajar. Selain penilaiannya, template lainnya yang disediakan ialah template bentuk dan metode pembelajaran [3].

Sistem Lective ini masih dalam proses pengembangan jadi dari pengguna kadang masih belum terbiasa dalam menggunakan perangkat ini dan masih sedikit dari dosen Universitas Muhammadiyah Malang yang menggunakan lective dalam pembuatan dan perancangan kurikulum karena kurangnya penerapan Lective di lingkungannya. Berdasarkan penjelasan tersebut dapat disimpulkan bahwa kurangnya penerapan Lective di lingkungan UMM merupakan salah satu faktor kendala dalam pengembangannya dikarenakan kesiapan dari penggunanya yaitu dosen yang masih kurang memahami secara penuh tentang penggunaan Lective.

Salah satu dari kendala pengembangan Lective adalah minimnya penerapan dilingkungan UMM yang didasarkan atas kurangnya kesiapan dari dosen pengampu untuk melaksanakan Lective dalam pembelajarannya. Kesiapan sendiri merupakan kondisi seseorang yang membuatnya siap untuk memberikan respon atau jawaban terhadap cara tertentu terhadap suatu situasi. Penyesuaian kondisi pada suatu saat akan berpengaruh atau kecenderungan untuk memberi respon [4].

Parasuraman mendefinisikan technology readiness (TR) sebagai "people's propensity to embrace and use new technology for accomplishing goal in home life and at work" sedang TRI merupakan indeks untuk mengukur kesiapan pengguna terhadap teknologi baru [5]. TRI menggunakan serangkaian pernyataan kepercayaan/keyakinan dalam melakukan survei untuk mengukur secara menyeluruh tingkat kesiapan teknologi dari individu. Parasuraman menyatakan TRI digunakan untuk mengukur kesiapan pengguna dalam menggunakan teknologi baru dengan indikator empat variabel kepribadian yaitu: optimism (optimisme), sikap pandang positif terhadap teknologi dan percaya bahwa teknologi akan meningkatkan kontrol, fleksibilitas, dan efisiensi dalam kehidupan [5]. Innovativeness (inovasi) sikap tendensi untuk yang pertama menggunakan produk maupun layanan teknologi baru. Discomfort (ketidaknyamanan) memiliki sikap sulit mengontrol dan cenderung kewalahan/tidak percaya diri ketika berhadapan dengan teknologi baru. Insecurity (ketidakamanan), memiliki kecurigaan terhadap keamaanan teknologi dan alasan keamanan data pribadi.

Kesiapan adalah keseluruhan kondisi seseorang yang membuatnya siap untuk memberikan respon atau jawaban terhadap cara tertentu terhadap suatu situasi. Penyesuaian kondisi pada suatu saat akan berpengaruh atau kecenderungan untuk memberi respon [4].

Pengukuran kesiapan pengguna merupakan hal penting dalam adopsi teknologi baru agar tujuan dari pengadopsian teknologi dapat tercapai dan lebih bermanfaat. Penelitian ini bertujuan untuk melakukan analisis kesiapan pengguna lective dengan mengadopsi metode Technology Readiness Index (TRI) yang dikembangkan oleh Parasuraman (2000). Metode ini dipilih karena TRI mampu membedakan dengan baik antara pengguna dan bukan pengguna sebuah teknologi, TRI mampu mengelompokkan pengguna berdasarkan keyakinan positif dan negatif terhadap teknologi yang lebih kompleks dan lebih futuristik, dan TRI mampu mengidentifikasi kelompokkelompok pengguna yang memiliki rasa ketidaknyamanan dan ketidakamanan secara signifikan karena TRI dibentuk oleh empat variabel kepribadian optimism, innovativeness, discomfort, dan insecurity [6].

\section{Metode Penelitian \\ 2.1 Studi Literatur}

Tahapan studi literatur merupakan tahapan pencarian informasi dan studi kepustakaan terhadap beberapa referensi yang berkaitan dengan teori-teori yang berkaitan. 


\subsection{Analisa kebutuan}

\subsubsection{Perumusan hipotesis}

Hipotesis adalah pernyataan atau dugaan yang bersifat sementara terhadap suatu masalah penelitian yang kebenarannya masih lemah (belum tentu kebenarannya) sehingga harus diuji secara empiris [7].

Model Konseptual atau konstruksi visualdari hipotesa yang akan dibuktikan dalam penelitian ini dapat dilihat pada Gambar 1.

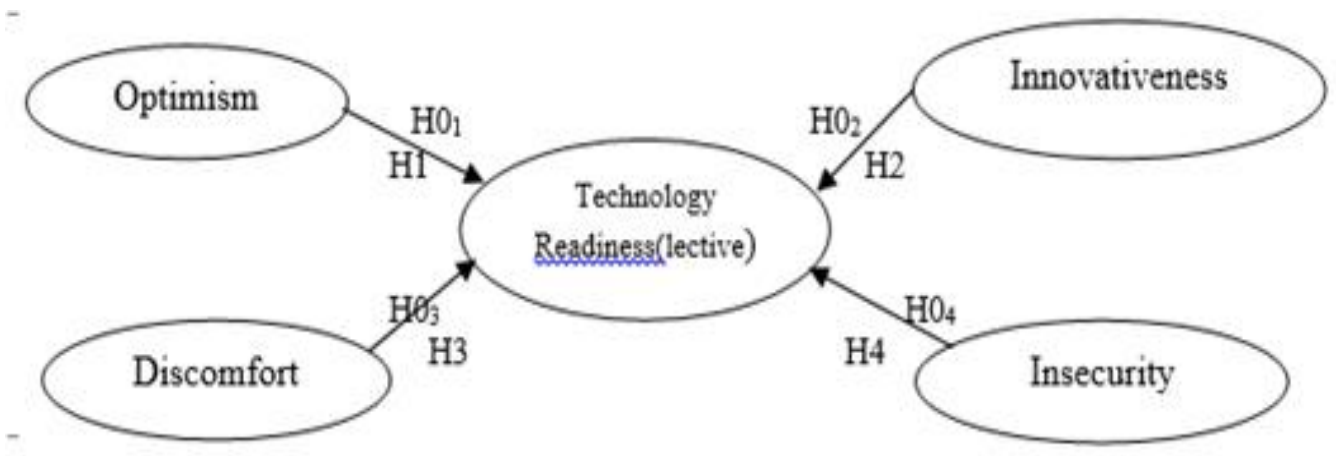

Gambar 1. Hipotesis Penelitian

Uji Hipotesis digunakan untuk menilai variabel yang telah dihipotesiskan, variabel dalam penelitian ini adalah Optimism, Innovativeness, Discomfort, dan Insecurity. Hipotesis yang digunakan untuk menilai masing-masing variabel seperti pada Tabel 1.

Tabel 1. Hipotesis Deskriptif

\begin{tabular}{|c|c|}
\hline No. & Hipotesis \\
\hline $\mathrm{H}_{1}$ & $\begin{array}{l}\text { Optimism tidak memiliki hubungan positif dan tidak berpengaruh secara } \\
\text { signifikan terhadap kesiapan teknologi }\end{array}$ \\
\hline $\mathrm{H} 1$ & $\begin{array}{l}\text { Optimism memiliki hubungan positif dan berpengaruh secara signifikan } \\
\text { terhadap kesiapan teknologi }\end{array}$ \\
\hline $\mathrm{HO}_{2}$ & $\begin{array}{l}\text { Innovativeness tidak memiliki hubungan positif dan tidak berpengaruh } \\
\text { secara signifikan terhadap kesiapan teknologi }\end{array}$ \\
\hline $\mathrm{H} 2$ & $\begin{array}{l}\text { Innovativeness memiliki hubungan positif dan berpengaruh secara } \\
\text { signifikan terhadap kesiapan teknologi }\end{array}$ \\
\hline $\mathrm{HO}_{3}$ & $\begin{array}{l}\text { Discomfort tidak memiliki hubungan positif dan tidak berpengaruh secara } \\
\text { signifikan terhadap kesiapan teknologi }\end{array}$ \\
\hline $\mathrm{H} 3$ & $\begin{array}{l}\text { Discomfort memiliki hubungan positif dan berpengaruh secara signifikan } \\
\text { terhadap kesiapan teknologi }\end{array}$ \\
\hline $\mathrm{HO}_{4}$ & $\begin{array}{l}\text { Insecurity tidak memiliki hubungan positif dan tidak berpengaruh secara } \\
\text { signifikan terhadap kesiapan teknologi }\end{array}$ \\
\hline $\mathrm{H} 4$ & $\begin{array}{l}\text { Insecurity memiliki hubungan positif dan berpengaruh secara signifikan } \\
\text { terhadap kesiapan teknologi }\end{array}$ \\
\hline
\end{tabular}

\subsubsection{Populasi dan Sampel}

Populasi dalam penelitian ini adalah seluruh pengguna Lective. Dari seluruh populasi akan diambil beberapa sampel untuk menjadi responden dalam penelitian ini. Penentuan sampel pada penelitian ini digunakan rumus Slovin pada Persamaan 1 [8].

$$
n=\frac{N}{1+N(e)^{2}}
$$

Keterangan:

$\mathrm{n}=$ Ukuran sampel

$\mathrm{N}=$ Ukuran populasi

e $=$ Taraf kesalahan error sebesar $0.05(5 \%)$ 


\subsubsection{Instrument Penelitian}

Instrumen penelitian yang digunakan adalah kuesioner. Item pengukuran pernyataan kuesioner didapatkan dari penelitian yang dilakukan oleh Parasuraman (2000). Item pengukuran kuesioner pada Tabel 2 terdiri dari 36 item Technology Readiness Index yang terdiri dari empat dimensi variable, yaitu Optimism, Innovativeness, Discomfort, dan Insecurity [5].

Tabel 2. Pertanyaan Kuisoner

\begin{tabular}{|c|c|}
\hline No. & Optimisme (Optimism) \\
\hline 1 & Lective dapat membuat saya lebih mudah dalam mendesain RPP dan RPS \\
\hline 2 & Layanan Lective nyaman untuk digunakan \\
\hline 3 & $\begin{array}{l}\text { Saya lebih suka membuat RPP dan RPS menggunakan Lective, karena saya } \\
\text { tidak perlu terpaku pada buku pedoman }\end{array}$ \\
\hline 4 & Saya lebih suka menggunakan Lective dalam merancang RPP dan RPS \\
\hline 5 & $\begin{array}{l}\text { Saya suka menggunakan tools dan fitur Lective yang dapat disesuaikan } \\
\text { dengan kebutuhan saya }\end{array}$ \\
\hline 6 & Lective membuat saya lebih efisien dalam merancang RPP dan RPS \\
\hline 7 & Saya merasa Lective dapat men \\
\hline 8 & Lective memberikan saya lebih banyak kebebasan dalam beraktifitas \\
\hline 9 & Dengan mempelajari Lective, saya jadi tidak ketinggalan informasi \\
\hline 10 & Saya merasa yakin bahwa Lective akan mengikuti instruksi yang saya berikan \\
\hline No & Inovasi (innovativeness) \\
\hline 1 & Banyak orang yang datang pada saya untuk meminta pendapat tentang Lective \\
\hline 2 & Teman-teman saya belajar lebih banyak tentang Lective daripada saya \\
\hline 3 & $\begin{array}{l}\text { Saya adalah orang pertama yang mengetahui tentang Lective dibandingkan } \\
\text { teman-teman lainnya }\end{array}$ \\
\hline 4 & $\begin{array}{l}\text { Saya dapat mengetahui perkembangan Lective dan layanan terbarunya tanpa } \\
\text { bantuan dari orang lain }\end{array}$ \\
\hline 5 & Saya mengikuti perkembangan Lective di bidang minat saya \\
\hline 6 & Saya menikmati tantangan untuk mencari tahu tentang fitur lective terbaru \\
\hline 7 & $\begin{array}{l}\text { Saya merasa mampu dan tidak mengalami banyak masalah dalam } \\
\text { menggunakan Lective }\end{array}$ \\
\hline No & Ketidaknyamanan (Discomfort) \\
\hline 1 & $\begin{array}{l}\text { Dukungan teknis terkadang tidak banyak membantu karena mereka tidak } \\
\text { menjelaskan hal-hal yang dapat saya mengerti }\end{array}$ \\
\hline 2 & Saya berpikir bahwa sistem Lective tidak dirancang untuk digunakan oleh orang biasa \\
\hline 3 & Tidak ditemukan panduan dalam layanan yang mudah dimengerti \\
\hline 4 & $\begin{array}{l}\text { Ketika saya mendapat dukungan teknis dari penyedia layanan Lective, saya } \\
\text { terkadang merasa seolah-olah saya dimanfaatkan oleh seseorang yang lebih tahu } \\
\text { daripada saya. }\end{array}$ \\
\hline 5 & $\begin{array}{l}\text { Pada saat saya membeli layanan Lective, saya lebih memilih model dasar } \\
\text { daripada yang memiliki fitur ekstra }\end{array}$ \\
\hline 6 & $\begin{array}{l}\text { Sangat memalukan bagi saya ketika memiliki masalah dengan Lective dan orang- } \\
\text { orang mengetahuinya }\end{array}$ \\
\hline & Harus ada kehati-hatian dalam mer \\
\hline 7 & $\begin{array}{l}\text { Permendikbud dengan Lective karena Lective dapat merusak peran } \\
\text { penting pada buku panduan }\end{array}$ \\
\hline 8 & $\begin{array}{l}\text { Lective bisa memiliki risiko kesehatan atau keselamatan yang tidak terlihat } \\
\text { sampai orang selesai menggunakannya }\end{array}$ \\
\hline 9 & $\begin{array}{l}\text { Lective membuat terlalu mudah bagi pemerintah dan perusahaan untuk } \\
\text { mengetahui aktifitas orang lain }\end{array}$ \\
\hline 10 & Lective terlalu sulit untuk digunakan \\
\hline No & Ketidakamanan (Insecurity) \\
\hline 1 & $\begin{array}{l}\text { Saya merasa tidak aman jika data yang saya simpan dapat dilihat oleh } \\
\text { orang lain }\end{array}$ \\
\hline 2 & $\begin{array}{l}\text { Saya merasa tidak aman jika data yang saya buat dapat dirubah oleh } \\
\text { orang lain tanpa seizin dari saya }\end{array}$ \\
\hline 3 & Saya khawatir jika informasi yang saya terima tidak asli. \\
\hline 4 & Saya merasa khawatir jika informasi atau data yang saya butuhkan tidak \\
\hline
\end{tabular}

REPOSITOR, Vol. 2, No. 7, Juli 2020: 923-932 
tersedia

5 Saya merasa khawatir jika ada hambatan dalam penerimaan informasi

6 Saya merasa khawatir jika lective tidak dapat diakses

$7 \quad$ Saya merasa khawatir jika data yang saya simpan di Lective dapat hilang atau terhapus

Saat merencanakan desain pembelajaran, saya lebih suka menggunakan buku pedoman secara langsung daripada menggunakan Lective.

9 Semua data yang telah saya buat harus saya cetak untuk menghindari data hilang atau server down ketika saat saya membutuhkannya

\subsection{Teknik Pengumpulan Data}

Teknik pengumpulan data yang digunakan dalam penelitian ini dengan skala Likert.[9] Skala likert menurut Sugiyono adalah skala yang digunakan untuk mengukur sikap, pendapat dan persepsi seseorang atau sekelompok orang tentang fenomena sosial. Bentuk dari skala likert menggunakan alternatif 5 pilihan jawaban yang harus diisi oleh subjek penelitian. Namun ada variasi lain yang menghapus respon netral[6]. Dan penelitian menggunakan variasi yang mengghapus respon netral. Tabel 3 berikut adalah sistem penilaian jenis item.

Tabel 3. Penilaian Skala Penelitian

\begin{tabular}{cc}
\hline Jawaban & Nilai \\
\hline Sangat Setuju & 4 \\
Setuju & 3 \\
Tidak Setuju & 2 \\
Sangat Tidak Setuju & 1 \\
\hline
\end{tabular}

\subsection{Uji Kelayakan Kuisoner}

Pengolahan data kuesioner dilakukan dengan menguji validitas data dan reliabilitas data. Uji validitas pada penelitian ini dilakukan untuk mengetahui dan mengukur data apa yang seharusnya diukur. Metode yang digunakan untuk uji validitas adalah Pearson Correlation Coefficient. Sedangkan uji reliabilitas dilakukan untuk melihat konsistensi data yang diambil melalui kuesioner yang telah disebarkan. Metode yang digunakan untuk uji reliabilitas disini adalah dengan menggunakan Cronbach's alpha

\section{Hasil Penelitian Dan Pembahasan}

Analisis Technology Readiness Index (TRI) bertujuan untuk mengukur tingkat kesiapan pengguna sistem Lective. Pengukuran mengadopsi metode Technology Readiness Index yang meliputi 4 variabel yaitu optimism, innovativeness, discomfort, dan insecurity.

\subsection{Pengumpulan Data}

Responden dalam penelitian ini adalah seluruh dosen-dosen pengguna Lective. Terdapat total 60 orang dosen yang telah menggunakan Lective. Dari seluruh populasi akan diambil beberapa sampel untuk menjadi responden dalam penelitian ini. Berdasarkan rumus Slovin dan menetapan taraf kesalahan 0.05 atau $5 \%$, maka jumlah responden penelitian adalah 52 orang. Responden dipilih menggunakan metode simple random sampling dimana setiap pengguna Lective memiliki peluang yang sama dan tidak terikat apapun untuk dimasukkan sebagai sampel penelitian. Setiap responden diminta memberikan penilaian berdasarkan Skala Likert.

\subsection{Deskripsi Responden}

Responden penelitian berjumlah 52 orang yang seluruhnya adalah dosen-dosen pengguna Lective. Profil responden berdasarkan dalam table 4 dimana 30 orang $(58 \%)$ laki-laki dan 22 orang perempuan (42\%). Tabel 4 berikut adalah deskripsi jenis kelamin responden.

Tabel 4. Deskripsi Jenis Kelamin Responden

\begin{tabular}{ccc}
\hline Jenis Kelamin & Jumlah & Persentase \\
\hline Laki-Laki & 30 Orang & $58 \%$ \\
Perempuan & 22 Orang & $42 \%$ \\
Jumlah & 52 Orang & $100 \%$ \\
\hline
\end{tabular}




\subsection{Uji Validitas}

Hal yang dilakukan dalam pengujian model pengukuran ini adalah melakukan uji validitas pada item-item pertanyaan yang ada dalam kuisioner. Kuisioner yang telah dikembalikan oleh responden akan diukur menggunakan tool SPSS.

Uji validitas pada penelitian ini dilakukan untuk mengetahui dan mengukur data apa yang seharusnya diukur. Pada penelitian ini, metode yang digunakan untuk uji validitas adalah Pearson Correlation Coefficient. Pada penelitian ini, data dinyatakan valid jika memiliki Pearson Correlation Coefficient ( $r$ hitung) lebih besar dari $r$ table.

Uji validitas Tabel 5 yang digunakan dalam penelitian ini adalah corellate bivariate pearson (korelasi product moment) dan $r$ tabel signifikan dengan $5 \%$. Dalam tahap pengujian ini jumlah responden sebanyak 25 orang sehingga bisa diketahui nilai $r$ tabel sebesar 0,396 , yang berarti alat ukur bisa dikatakan valid apabila $r$ hitung lebih besar dari $r$ tabel sedangkan jika nilai $r$ hitung lebih kecil dari $r$ tabel maka alat ukur bisa dikatakan tidak valid.

Tabel 5. Hasil Uji Validitas

\begin{tabular}{|c|c|c|c|}
\hline No. Pertanyaan & Nilai r Hitung & Nilai r Tabel & Keterangan \\
\hline 1 & 0,246 & 0,396 & Tidak Valid \\
\hline 2 & 0,486 & 0,396 & Valid \\
\hline 3 & 0,465 & 0,396 & Valid \\
\hline 4 & 0,655 & 0,396 & Valid \\
\hline 5 & 0,465 & 0,396 & Valid \\
\hline 6 & 0,325 & 0,396 & Tidak Valid \\
\hline 7 & 0,462 & 0,396 & Valid \\
\hline 8 & 0,498 & 0,396 & Valid \\
\hline 9 & 0,485 & 0,396 & Valid \\
\hline 10 & 0,168 & 0,396 & Tidak Valid \\
\hline 11 & 0,552 & 0,396 & Valid \\
\hline 12 & 0,075 & 0,396 & Tidak Valid \\
\hline 13 & 0,304 & 0,396 & Tidak Valid \\
\hline 14 & 0,545 & 0,396 & Valid \\
\hline 15 & 0,571 & 0,396 & Valid \\
\hline 16 & 0,841 & 0,396 & Valid \\
\hline 17 & 0,167 & 0,396 & Tidak Valid \\
\hline 18 & 0,524 & 0,396 & Valid \\
\hline 19 & 0,386 & 0,396 & Tidak Valid \\
\hline 20 & 0,420 & 0,396 & Valid \\
\hline 21 & 0,670 & 0,396 & Valid \\
\hline 22 & 0,022 & 0,396 & Tidak Valid \\
\hline 23 & 0,525 & 0,396 & Valid \\
\hline 24 & 0,594 & 0,396 & Valid \\
\hline 25 & 0,465 & 0,396 & Valid \\
\hline 26 & 0,632 & 0,396 & Valid \\
\hline 27 & 0,391 & 0,396 & Tidak Valid \\
\hline 28 & 0,584 & 0,396 & Valid \\
\hline 29 & 0,514 & 0,396 & Valid \\
\hline 30 & 0,779 & 0,396 & Valid \\
\hline 31 & 0,893 & 0,396 & Valid \\
\hline 32 & 0,784 & 0,396 & Valid \\
\hline 33 & 0,842 & 0,396 & Valid \\
\hline 34 & 0,761 & 0,396 & Valid \\
\hline 35 & 0,424 & 0,396 & Valid \\
\hline 36 & 0,424 & 0,396 & Valid \\
\hline
\end{tabular}

Berdasarkan uji korelasi, terdapat 9 pertanyaan yang tidak valid yaitu nomor $1,6,10,12,13,17,19,22$ dan 27 . Item pertanyaan yang tidak valid tidak dapat digunakan dalam kuisioner[10]. Peneliti memilih untuk membuang item-item soal yang tidak valid setelah dilakukan pengujian atau dengan kata lain tidak mengikutkan nilai item angket yang tidak valid dalam 
perhitungan selanjutnya. Maka hasil item pertanyaan dapat dilihat pada Tabel 6 setelah membuang item-item soal yang tidak valid.

Tabel 6. Pernyataan Kuisoner Setelah Uji Validasi

\begin{tabular}{|c|c|}
\hline No. & Optimisme (Optimism) \\
\hline 1 & Layanan Lective nyaman untuk digunakan \\
\hline 2 & $\begin{array}{l}\text { Saya lebih suka membuat RPP dan RPS menggunakan Lective, karena saya } \\
\text { tidak perlu terpaku pada buku pedoman }\end{array}$ \\
\hline 3 & Saya lebih suka menggunakan Lective dalam merancang RPP dan RPS \\
\hline 4 & $\begin{array}{l}\text { Saya suka menggunakan tools dan fitur Lective yang dapat disesuaikan } \\
\text { dengan kebutuhan saya }\end{array}$ \\
\hline $\begin{array}{l}5 \\
6 \\
7\end{array}$ & $\begin{array}{l}\text { Saya merasa Lective dapat mendorong untuk mengerjakan tugas saya } \\
\text { Lective memberikan saya lebih banyak kebebasan dalam beraktifitas } \\
\text { Dengan mempelaiari Lective, sava jadi tidak ketingaalan informasi }\end{array}$ \\
\hline No & Inovasi (innovativeness) \\
\hline 1 & Banyak orang yang datang pada saya untuk meminta pendapat tentang Lective \\
\hline 2 & $\begin{array}{l}\text { Saya dapat mengetahui perkembangan Lective dan layanan terbarunya tanpa } \\
\text { bantuan dari orang lain }\end{array}$ \\
\hline 3 & Saya mengikuti perkembangan Lective di bidang minat saya \\
\hline 4 & Saya menikmati tantangan untuk mencari tahu tentang fitur lective terbaru \\
\hline No & Ketidaknyamanan (Discomfort) \\
\hline 1 & $\begin{array}{l}\text { Dukungan teknis terkadang tidak banyak membantu karena mereka tidak } \\
\text { menjelaskan hal-hal yang dapat saya mengerti }\end{array}$ \\
\hline 2 & $\begin{array}{l}\text { Tidak ditemukan panduan dalam layanan yang mudah dimengerti } \\
\text { Ketika saya mendapat dukungan teknis dari penyedia layanan Lective, saya }\end{array}$ \\
\hline 3 & $\begin{array}{l}\text { terkadang merasa seolah-olah saya dimanfaatkan oleh seseorang yang lebih tahu } \\
\text { daripada saya. }\end{array}$ \\
\hline 4 & $\begin{array}{l}\text { Sangat memalukan bagi saya ketika memiliki masalah dengan Lective dan orang- } \\
\text { orang mengetahuinya }\end{array}$ \\
\hline & Harus ada kehati-hatian dalam mengganti buku panduan dari \\
\hline 5 & $\begin{array}{l}\text { Permendikbud dengan Lective karena Lective dapat merusak peran } \\
\text { penting pada buku panduan }\end{array}$ \\
\hline 6 & $\begin{array}{l}\text { Lective bisa memiliki risiko kesehatan atau keselamatan yang tidak terlihat } \\
\text { sampai orang selesai menggunakannya }\end{array}$ \\
\hline 7 & $\begin{array}{l}\text { Lective membuat terlalu mudah bagi pemerintah dan perusahaan untuk } \\
\text { mengetahui aktifitas orang lain }\end{array}$ \\
\hline No & Ketidakamanan (Insecurity) \\
\hline 1 & $\begin{array}{l}\text { Saya merasa tidak aman jika data yang saya simpan dapat dilihat oleh } \\
\text { orang lain }\end{array}$ \\
\hline 2 & $\begin{array}{l}\text { Saya merasa tidak aman jika data yang saya buat dapat dirubah oleh } \\
\text { orang lain tanpa seizin dari saya }\end{array}$ \\
\hline 3 & Saya khawatir jika informasi yang saya terima tidak asli. \\
\hline 4 & $\begin{array}{l}\text { Saya merasa khawatir jika informasi atau data yang saya butuhkan tidak } \\
\text { tersedia }\end{array}$ \\
\hline 5 & Saya merasa khawatir jika ada hambatan dalam penerimaan informasi \\
\hline 6 & Saya merasa khawatir jika lective tidak dapat diakses \\
\hline 7 & $\begin{array}{l}\text { Saya merasa khawatir jika data yang saya simpan di Lective dapat } \\
\text { hilang atau terhapus }\end{array}$ \\
\hline 8 & $\begin{array}{l}\text { Saat merencanakan desain pembelajaran, saya lebih suka menggunakan } \\
\text { buku pedoman secara langsung daripada menggunakan Lective. }\end{array}$ \\
\hline 9 & $\begin{array}{l}\text { Semua data yang telah saya buat harus saya cetak untuk menghindari data } \\
\text { hilang atau server down ketika saat saya membutuhkannya }\end{array}$ \\
\hline
\end{tabular}

\subsection{Uji Reliabilitas}

Uji reliabilitas dilakukan untuk melihat konsistensi data yang diambil melalui kuesioner yang telah disebarkan. Metode yang digunakan untuk uji reliabilitas disini adalah dengan 
menggunakan Cronbach's alpha. Hasil uji reliabilitas dapat dilihat dari koefesien cronbach's alpha dengan perhitungan menggunakan SPSS, sehingga dapat diperoleh hasil koefesien cronbach's alpha pada Tabel 7 berikut.

\begin{tabular}{cc}
\multicolumn{2}{c}{$\begin{array}{c}\text { Tabel 7. Hasil Uji } \\
\text { Reliability Stabilistics }\end{array}$} \\
\hline Cronbach's Alpha & N of Items \\
\hline .931 & 27 \\
\hline
\end{tabular}

Uji reliabilitas dalam penelitian ini menghasilkan nilai cronbach's alpha sebesar 0,931. Berdasarkan tingkat reliabilitas Cronbach's Alpha nilai 0,931 berada pada range $0,80<r<11 \leq 1,00$ sehingga hasil dari pengujian menunjukkan bahwa reliabilitas dari kuesioner sangat tinggi. Maka dari itu, instrumen pertanyaan dan jawaban dapat dikatakan reliable sehingga dapat dilakukan pengolahan data lebih lanjut.

\subsection{Analisis dan Hasil Pengolaan Data}

Analisis hasil pengolahan data terbagi menjadi dua tahap, yaitu Uji T dan Uji F. Uji hipotesis dilakukan terhadap dosen-dosen pengguna Lective.

\subsubsection{Uji T}

Pada uji t digunakan untuk mengetahui ada atau tidaknya hubungan variabel - variabel bebas seperti Optimism, Inovativeness, Discomfort dan Insecurity dengan variable terikat yaitu Technology Readines atau kesiapan pengguna Lective. Hasil dari uji t dapat dilihat pada Tabel 8.

Tabel 8. Hasil Uji T

\begin{tabular}{cccc}
\hline & Model & $\mathrm{t}$ & Sig. \\
\hline \multirow{4}{*}{1} & (Constant) & .723 & .473 \\
& optimism & -.090 & .929 \\
& innovativeness & 1.390 & .171 \\
& discomfort & 1.043 & .302 \\
& insecurity & -1.326 & .191 \\
\hline
\end{tabular}

Jika nilai prob. t hitung lebih kecil dari tingkat kesalahan (alpha) 0,05, maka dapat disimpulkan bahwa variabel bebas dari thitung tersebut berpengaruh signifikan terhadap variabel terikatnya. Namun jika nilai prob. $t$ hitung lebih besar dari tingkat kesalahan 0,05 maka dapat dikatakan bahwa variabel bebas tidak mempengaruhi signifikan terhadap variable terikatnya. Adapun hasil dari tabel diatas dapat dijabarkan sebagai berikut:

1. Hipotesis 1

Menyatakan bahwa variabel Optimism memiliki statistik uji t sebesar 0,929 . Apabila nilai signifikansi lebih besar dari a $(0,05)$, dapat disimpulkan bahwa H0 diterima dan H1 ditolak sehingga dapat dikatakan bahwa variabel Optimism tidak berpengaruh secara signifikan terhadap kesiapan pengguna Lective (Technology Readiness).

\section{Hipotesis 2}

Menyatakan bahwa variabel Inovativeness memiliki statistik uji t sebesar 0,171 . Apabila nilai signifikansi lebih besar dari a $(0,05)$, dapat disimpulkan bahwa $\mathrm{H} 0$ diterima dan $\mathrm{H} 1$ ditolak sehingga dapat dikatakan bahwa variabel Innovativeness tidak berpengaruh secara signifikan terhadap kesiapan pengguna Lective (Technology Readiness).

\section{Hipotesis 3}

Menyatakan bahwa variabel Discomfort memiliki statistik uji t sebesar 0,302 . Apabila nilai signifikansi lebih besar dari a $(0,05)$, dapat disimpulkan bahwa H0 diterima dan $\mathrm{H} 1$ ditolak sehingga dapat dikatakan bahwa variabel Discomfort tidak berpengaruh secara signifikan terhadap kesiapan pengguna Lective (Technology Readiness). 
4. Hipotesis 4

Menyatakan bahwa variabel Insecurity memiliki statistik uji t sebesar 0,191. Apabila nilai signifikansi lebih besar dari a $(0,05)$, dapat disimpulkan bahwa $\mathrm{H} 0$ diterima dan $\mathrm{H} 1$ ditolak sehingga dapat dikatakan bahwa variabel Insecurity tidak berpengaruh secara signifikan terhadap kesiapan pengguna Lective (Technology Readiness).

\subsubsection{Uji F}

Uji keterandalan model atau biasanya disebut dengan uji $F$ bertujuan untuk mengetahui hubungan antara variabel bebas dan variable terikat. Pada penelitian ini apakah variabel Optimism, Innovativeness, Discomfort dan Insecurity memiliki pengaruh secara simultan terhadap variable kesiapan pengguna (Technology Readiness). Pengujian ini disebut dengan uji F karena mengikuti distribusi F yang kriteria pengujiannya seperti One Way Anova. Jika nilai prob. F hitung (jika pada keluaran SPSS ditunjukkan pada kolom sig.) lebih kecil dari tingkat kesalahan (error alpha) 0,05, maka dapat dikatakan bahwa model regresi yang diestimasi layak, namun jika nilai prob. F hitung lebih besar dari tingkat kesalahan 0,05 maka dapat disimpulkan bahwa model regresi yang diestimasi tidak layak. Hasil uji F dapat dilihat pada Tabel 9.

Tabel 9. Hasil Uji $F$

\begin{tabular}{|c|c|c|c|c|c|c|}
\hline \multicolumn{7}{|c|}{$\begin{array}{c}\text { Tabel 9. Hasil Uji F } \\
\text { ANOVA }^{\mathbf{b}}\end{array}$} \\
\hline & Model & Sum of Squares & df & Mean Square & $\mathrm{F}$ & Sig. \\
\hline \multirow{3}{*}{1} & Regression & 788.905 & 4 & 197.226 & .849 & $.502^{a}$ \\
\hline & Residual & 10924.095 & 47 & 232.428 & & \\
\hline & Total & 11713.000 & 51 & & & \\
\hline
\end{tabular}

a. Predictors: (Constant), insecurity, optimism, innovativeness, discomfort

b. Dependent Variable: technology_readiness

Menurut tabel ANOVA atau uji $\mathrm{F}$ diatas, didapatkan nilai $\mathrm{F}$ hitung sebesar 0,849 dengan probabilitas 0,502 . Karena probabilitas pada hasil uji $F$ lebih besar dari 0,05 , maka dapat disimpulkan bahwa koefisien regresi untuk variable Optimism, Innovativeness, Discomfort dan Insecurity tidak sama dengan 0 , atau dengan kata lain keempat variabel bebas secara simultan tidak berpengaruh terhadap variabel terikat yaitu kesiapan pengguna Lective. Hal ini juga menunjukkan bahwa nilai koefisien determinasi R2 tidak sama dengan 0 atau tidak signifikan.

\section{Kesimpulan}

Penelitian ini menganalisa kesiapan pengguna lective. Lective merupakan sebuah perangkat pembelajaran berbasis online yang merupakan sarana pembelajaran bagi dosen untuk mendesain Rencana Pembelajaran Semester (RPS) dan Rencana Pelaksanaan Pembelajaran (RPP). Metode penelitian ini menggunakan Technology Readiness Index (TRI) yang memiliki 4 dimensi variabel yaitu Optimism, Inovativeness, Discomfort, dan Insecurity. Dari hasil pengujian menggunakan alat bantu SPSS, disimpulkan sebagi berikut:

1. Optimisme pengguna tidak berpengaruh terhadap Lective

2. Innovasi pengguna tidak berpengaruh terhadap Lective

3. Ketidaknyamanan pengguna tidak berpengaruh terhadap Lective

4. Ketidakamanan pengguna tidak berpengaruh terhadap Lective.

\section{Referensi}

[1] M. Y. Florestiyanto, "Evaluasi Kesiapan Pengguna Dalam Adopsi Sistem Informasi Terintegrasi di Bidang Keungan Menggunakan Metode Technology Readiness Index," vol. 2012, no. semnasIF, pp. 288-296, 2012.

[2] G. W. Wicaksono, H. W. Asrini, and M. A. Al-Rizki, "Desain Perangkat Pembelajaran Pendidikan Tinggi dengan Sistem Lective Gegulang ${ }^{\mathrm{TM}}$," J. Nas. Tek. Elektro dan Teknol. Inf., vol. 6, no. 4, pp. 416-422, 2018.

[3] G. W. Wicaksono, H. W. Asrini, and D. Iswatiningsih, "Desain Kurikulum Program Studi Teknik Informatika Universitas Muhammadiyah Malang dengan tools Lective Huluakan," pp. 432-440, 2017. 
[4] Slameto, Belajar dan Faktor-faktor yang Mempengaruhinya. Jakarta: Rineka Cipta, 2003.

[5] A. Parasuraman, "Technology Readiness Index (Tri): A Multiple-Item Scale to Measure Readiness to Embrace New Technologies," J. Serv. Res., 2000.

[6] R. Noprianto, W. W. Winarno, and W. Najib, "Evaluasi Kesiapan Pengguna Dalam Adopsi Sistem Informasi Manajemen SEIP Menggunakan Metode Technology Readiness Index," J. Buana Inform., 2017.

[7] Erwan Agus Purwanto and D. R. Sulistyastuti, Metode Penelitian Kuantitatif untuk Administrasi Publik dan Masalah-Masalah Sosial. Yogyakarta: Gaya Media, 2007.

[8] Sugiono, Metode Penelitian Kunatitatif Kualitatif dan R\&D. Bandung: Alfabeta, 2008.

[9] Sugiono, Metodologi Penelitian Bisnis. Jakarta: PT. Gramedia, 2007.

[10] B. A. Priatna, "Uji Coba Instrumen Penelitian dengan Menggunakan MS Excel dan SPSS," no. November, pp. 1-22, 2008. 